Jeppe Høst, Ph.d. og cand. mag. i Europæisk Etnologi, Postdoc, afdelingen for Etnologi, Saxo-Instituttet, Københavns Universitet. Artiklen er baseret på forfatterens Ph.d.-afhandling "Captains of Finance: An enquiry into market-based fisheries management", som er en etnologisk, empirisk og teoretisk udforskning af privatisering af fiskekvoter.

Nøgleord: Fiskeri, privatisering, fiskekvoter, naturressourceforvaltning, markedsgørelse

\title{
KVOTE OG FISK PÅ DET FRIE MARKED
}

Et af de centrale redskaber i forvaltningen af dansk fiskeri har siden 1970erne været fiskekvoter. Kvoterne satte en øvre grænse for, hvor store mængder fisk Danmark måtte udtage af sine farvande, og blev dermed det centrale bindeled mellem naturressourcen, fiskere og forvaltning. Disse kvoter blev forvaltet som et fælles gode, indtil de fra omkring 2001 blev opdelt, privatiseret og tildelt de individuelle fartøjsejere. Denne artikel undersøger først kvotesystemets historiske oprindelse, som findes $i$ et spænd mellem havbiologi, mellemstatsligt samarbejde og fiskernes fangstpraksisser. Herefter fokuserer jeg i artiklen på konsekvenserne af privatiseringen af fiskeressourcerne og gennem empirisk materiale udfoldes en række eksempler, der viser, hvordan markedet, forvaltningen og de forskellige fangstpraksisser sameksisterer med fiskekvoten som det centrale omdrejningspunkt. Et grundlæggende spørgsmål bliver for kvoteejerne - og for artiklen - at finde grundlaget for kvoternes værdi samt at forstå, hvordan kvoter som handelsvare knytter fisken som naturressource sammen med både marked og fiskere.

\section{Det frie fiskeri og partsfiskeriet}

Med de lange kyster, øer og mange fjorde har fiskeriet været en vigtig aktivitet op i gennem den danske kulturhistorie. Middelalderens store sildefangster gav vigtige skatteindtægter og grobund for international handel, mens det i det 20. århundrede var entreprenante fiskere i samarbejde med lokale håndværkere, der skabte 
de redskaber og teknikker, der muliggjorde vækst og en ny storhedstid for dansk fiskeri (Søndergaard 2004; 2008). Med danskopfundne teknologier som snurrevoddet, den hydrauliske garnhaler og larsen-trawlet kunne de danske partsfiskere i det 20. århundrede drive et internationalt og konkurrencedygtigt fiskeri. Partsfiskernes særlige organisationsform, hvor fangsten deles i parter mellem mand, båd og redskaber, viste sig i stand til at konkurrere med blandt andet britiske og tyske rederier på trods af deres større både og investeringer i redskaber (Hjorth Rasmussen 1968; 1984; Højup 1984; Rasmussen og Hjorth Rasmussen 1972). Fra 1900 til 1980 mangedoblede de danske fangster sig fra 175.000 tons til omkring 2 millioner tons, samtidig med at antallet af fiskere var nogenlunde stabilt omkring 15.000. Den store vækst i fangsterne skyldtes for en stor del fremkomsten af industrifiskeriet, som tilføjede nye arter og metoder til fangsterne. I fiskeriets selvforståelse så man erhvervet som det frie og liberale erhverv, hvor arbejdsomme og dygtige unge mænd kunne udfolde et liv som frie og uafhængige producenter. Hertil kom den frihedsfølelse som havde sin rod i arbejdets frie karakter på havet og som fangstpraksis, i kontrast til de urbaniserede og landbaserede erhverv. Denne frihed var til dels også rodfæstet i de sparsomme reguleringer, som forvaltede fiskeriet, og som primært fastsatte maskestørrelser på redskaber, mindstestørrelser på de fisk, der måtte fanges, samt enkelte bestemmelser omkring lukkede sæsoner og områder. Med den store vækst i fangster og den teknologiske udvikling i fangstudstyr kom fiskeriet frie karakter under pres. I 1974 indførtes den første fiskekvote i Nordsøen, nemlig for den hårdt belastede nordsøsild. I månederne efter fulgte én efter én kvoter for en lang række af de vigtigste konsumfisk i Danmark. Fra Nordsøen spredte kvoterne sig som forvaltningsredskab hurtigt til de indre farvande og Østersøen. Fiskekvoter blev derfor relativt hurtigt det naturlige udgangspunkt for fiskeriforvaltningen både i Danmark og mellem landene i Nordeuropa, og man kan retrospektivt tale om et paradigmatisk skifte i fiskeri- og naturforvaltningen fra regulering af redskaberne til styring af fiskeriet gennem den maksimale tilladte fangst. Med dette skifte fulgte også nye videnskaber, modeller og opbygning af nye datasæt. Fiskekvoterne skulle, selvom de var hadet og udskældt af fiskerne, vise sig at være kommet for at blive og fik hurtigt større og større indflydelse på fiskernes dagligdag. Selvom fiskekvoternes indførelse havde sin baggrund i en biologisk bekymring for fiskebestandene, så blev fiskekvoternes konkrete udformning præget af den politiske udfordring det var at dele de begrænsede fiskemuligheder mellem nordsølandene.

\section{Kvoteregimets baggrund}

For hvordan forvaltes og kontrolleres et internationalt sammensat fiskeri som det i Nordsøen? Som nævnt var det i biologisk forstand bekymringer over fiskebe- 
standene, særligt nordsøsilden, der var drivkraften bagved kvotesystemets fødsel. Men at det lige blev kvoter, som blev det endelige resultat af denne bekymring, skyldes flere ting og ikke bare videnskabelig fremgang og indsigt i fiskeriets påvirkning af bestandene. Selv om der i 1950erne og 1960erne var kommet videnskabelige gennembrud, teknologier og modeller, der gjorde det muligt matematisk at beregne og estimere bestandsstørrelse, så var det i lige så høj grad kvotens evner og egenskaber i en politisk kontekst, som for alvor gav den medvind i 1970erne (Holm 2001; Holm og Nielsen 2007; Rozwadowski 2002). Kvoter tildelte nemlig klare rollefordelinger mellem biologer, fiskere og politikere. Sidstnævnte fik et objekt, der kunne formes og forhandles i mellemstatslige møder, men som samtidig kunne indrettes efter nationale særhensyn. Dette var vigtigt, da fiskebestande og fartøjerne bevægede sig over store områder i de internationale farvande. Hvert land havde deres særlige fiskeri og traditioner, og en regulering af fiskeriet skulle derfor samtidig have international legitimitet, hvis en beskyttelse af bestanden skulle nytte noget. Denne dynamik mellem den internationale dimension i fiskeriet og det nationale fik stor betydning for kvoternes indførsel og udbredelse af fiskekvoter som det centrale forvaltningsredskab. Det var i begyndelsen af 1970erne nemlig mere og mere klart, at den internationale politiske udvikling ville lede mod en udvidelse og standardisering af de eksklusive økonomiske havzoner til 200 sømil (Rozwadowski 2002). Rundt om Nordsøen gik de nationale zoner på dette tidspunkt mellem tre og tolv sømil ud fra kysten, og i zonerne var ressourcerne i havet (fiskene) og havbunden (olien) forbeholdt den pågældende stat. En udvidelse af zonen til 200 sømil ville derfor være en betydelig omvæltning i fiskernes årlige bevægelsesfrihed og sæsoner rundt omkring på Nordsøen. Nordsøen ville geopolitisk se anderledes ud. En sådan udvidelse var allerede indført unilateralt i enkelte lande (f.eks. USA) og varslet af andre, heriblandt Island (Nandan 2012:online document; Rozwadowski 2002). Selvom det også ville sikre Danmark en større eksklusiv national zone, ville det også betyde begrænsninger af fiskeriet. I nordeuropæisk kontekst ville det radikalt ændre på fordelingen mellem lukkede nationale og åbne internationale farvande. Det ville især ramme det fiskeriet fra den jyske vestkyst:

„...for dansk fiskeri er det simpelthen et spørgsmål om en fremtid eller ej, at der skabes en regional særordning for Nordsøen. Zoner uden særaftale med Storbritannien vil for alvor skabe krise i danske fiskerihavne.“

Leder i „Vestkysten“ her citeret fra Dansk Fiskeri Tidende 10. april 1975.

Samtidig havde hvert land indrettet sit fiskeri efter nordsøsilden på vidt forskellige måder, og nordsølandene beskyldte hinanden for at være skyld i overfiskeriet. De danske trawlere fik skæld ud for at fange sildene mens de stadig var ungsild, de højeffektive norske snurpenotbåde blev beskyldt for i løbet af få timer at fjerne 
hele stimer af fisk, mens de belgiske bomtrawlere blev hængt ud for at ødelægge havbunden langs den jyske vestkyst (Karlsdóttir 2005). Her tilbød kvoten som forvaltningsprincip og forhandlingsobjekt en mulighed for mellemstatsligt at aftale en maksimal grænse for den tilladte fangst, mens at denne kunne udstykkes i kvoter som så sidenhen kunne fiskes efter nationale præferencer. Fordelingen af den samlede kvote mellem landene blev udregnet efter fangster over en tiårig periode, og disse procentsatser - kendt som den „relative stabilitet“ - er stort set bevaret indtil i dag, hvilket illustrerer kvotens levedygtighed og politiske egenskaber (Holm 2001; Holm og Nielsen 2007). Den prekære biologiske situation kunne være håndteret med andre strategier, for eksempel ved at frede eller helt lukke sildefiskeriet, ved at begrænse mængden af fartøjer eller ved i højere grad at regulere typerne af fangstredskaber. At det lige blev fiskekvoter, som vi kender dem i dag, har dermed også sine grunde i de politiske egenskaber, kvoterne havde. Kvoterne var dog ikke populære blandt fiskerne og var også et væsentligt brud med frihedsfølelsen i deres erhverv. At forvalte fiskeriet med kvoter blev anskuet som et nødvendigt onde. Men mere end blot at være en øvre grænse for fiskeriet kom kvoterne hurtigt til at få indflydelse på en lang række grundlæggende forhold. I én forstand kan man sige, at fiskerne nu fangede kvote i stedet for fisk, og at fiskeriet blev yderligere spundet ind i et internationalt net af havbiologi og storpolitik. Det var med andre ord begyndelsen til enden på det frie fiskeri, for med kvoteregimet indførtes et nyt hierarki og en årscyklus, hvor fiskerne kom til at blive klemt mellem fiskeribiologi og mellemstatslig politik. Således opsummerede Dansk Fiskeri Tidende selv i en artikel fra 1974 situationen:

„Kvote er et ord, der får mange til at rejse børster, fordi de opfatter det som en utidig indgriben i deres lovlige metier. I århundreder har man kunnet fiske uhindret, for havets rigdomme syntes uudtømmelige, men nu er de pludselig blevet rationerede. I dag fanges fiskene på biologernes regnemaskiner og ved fiskerikommissionernes forhandlingsborde, før de fanges af fiskerne. Det kræver et stedse mere intensivt samarbejde mellem fiskerierhvervet og forskningen." (Dansk Fiskeri Tidende 19. december 1974).

Kvoterne var ikke en midlertidig nødforanstaltning, som mange håbede. Tværtimod, for kvoterne spredte sig hastigt som forvaltningsmodel fra Nordsøen og ud i hele Nordeuropa og blev i 1983 for Danmarks vedkommende institutionaliseret i EFs fælles fiskeripolitik. Det, der var en optimal løsning på mellemstatsligt niveau, viste sig dog hurtigt at være en besværlig forvaltningsmodel til indenrigs brug. Det var især torskefiskeriet, som hurtigt viste de nye aspekter af kvotereguleringen. Allerede i januar 1975 - altså efter blot en måned i det nye kvoteregime - begyndte flere af nordsøfiskerne at bekymre sig. Da den danske kvote var fælles for alle fiskere, frygtede de, at kvoten for 1975 for hurtigt ville blive fisket op og 
efterlade dem uden indtægtsgrundlag senere på året (Dansk Fiskeri Tidende 30. januar 1975). På trods af disse bekymringer, blev der samtidig landet så store mængder af torsk, at markedet ikke kunne aftage fisken til en ordentlig pris (se blandt andet Dansk Fiskeri Tidende 27. februar og 6. marts 1975). Fiskernes producent organisation måtte købe fisken op til mindstepris for at sælge den videre som dyrefoder. Da kvoten altså var et fælles gode, var der skabt et incitament for fiskerne til at sikre sig, at deres egen del blev så stor som mulig. Det problematiske i en fælles kvote viste sig altså hurtigt. Problemet var systemisk, men særligt garnfiskerne var udsatte, da deres redskabsform krævede mere tid, men til gengæld ofte leverede en bedre kvalitet. Således udtaler en garnfisker i marts 1975:

„Trawlerne tager torskene for næsen af os, og når kvoten er brugt op, fisker de skidtfisk - mens vi er på den [...] Det er et stort problem for os.“ (Dansk Fiskeri Tidende 6. marts 1975).

De nye indbyggede konflikter i kvotesystemet viste sig altså hurtigt efter dets indførelse, og det var særligt den intense kamp om den begrænsede mængde kvote, der var ødelæggende for erhvervet, da det gav incitamenter til at bygge større fartøjer samtidig med, at de store landinger pressede prisen i bund. I 1979 fik fiskeriministeren derfor myndighed til at dele og forvalte kvoterne for at imødekomme de hurtige og uforudsigelige udviklinger i fiskeriet (Søndergaard 2008). Det var begyndelsen til 1980ernes såkaldte „,rationsfiskeri“, hvor kvoten skridt for skridt blev delt op og allokeret til fartøjerne i rationer efter stadigt mere komplekse principper. Det førte for nogle arter til at rationen kun blev meldt ud for en uge eller to ad gangen. Stadig var der grundlæggende tale om en fælles kvote. Fangsttallene skulle dynamisk indregnes i modellen, før nye rationer kunne meldes ud, hvilket skabte svingende fangstmængder og usikkerhed i erhvervet. Ministerens redskaber var begrænset til at opdele kvoten i farvande, bådstørrelser og i tidsenheder, og med den samtidige teknologiske udvikling og støtte til nybygninger og investeringer udviklede fiskeriet sig samlet set uhensigtsmæssigt. Derfor blev der løbende fra 1980erne og frem forsøgt at finde andre modeller for fiskeriets forvaltning. Heriblandt var forslag om individuelle licenser, afgiftsbetaling og også om individuelt omsættelige kvoter (IOK), altså en privatisering af kvoterne. Men forslagene mødte hver gang modstand i fiskeriforeningerne, som frygtede ændringerne ville ødelægge fiskeriets fleksibilitet og tilpasningsevne (Søndergaard 2008). I 1990erne fortsatte således rationsfiskeriet og kvotesystemets indre dynamik, samtidig med at nye aktivitetskrav, ophugningsordninger og begrænsninger på nye investeringer gjorde fiskeriet endnu mere presset og splittet (Byskov 2010; Vedsmand, Friis og Raakjær 1996; Vedsmand 1998). Morten Karnøe Søndergaard opsummerer i sin Ph.d. afhandling udviklingen i 1990ernes fiskeri således: 
„Øverst i hierarkiet stod ejerne af de store notbåde og trawlere, der støttet af fiskeindustrien og fiskeeksportørerne mere end gerne fulgte de udviklingslinjer med IOK [private kvoter], som var under planlægning i ministeriet. Nederst i hierarkiet stod kystfiskerne, som man blev ved med at love en særordning, der dog gang på gang blev sendt i udvalg eller udskudt. Medens kystfiskeriet blev offer for en „forhalingsstrategi“, blev ejerne af de mellemstore trawlere, som var fanget mellem de to grupper, udsat for en langsom kvælningsdød, idet manglende muligheder for langtidsplanlægning kombineret med dårlig økonomi betød at stadig flere i denne gruppe måtte trække sig ud af erhvervet.“ (Søndergaard 2008, s. 242).

Den omfattende forvaltningsform og åbenlyse modsætninger fiskerne i mellem øgede med tiden presset for at finde en politisk løsning på fiskeriet.

\section{Privatiseringen af fiskeriet}

Helt tilbage fra 1980erne havde det altså fra ministeriet og blandt andet fiskeopkøberne været foreslået at privatisere kvoterne ved at give dem som privat ejendom til fartøjsejerne, men denne ide var gang på gang blevet forkastet som et brud på fiskeriets lighedsprincipper og som en hindring af fiskeriet tilpasningsevne. Den biologiske forvaltning var blevet styrket med indførsel af kvoter, mens den økonomiske situation langsomt blev forværret. Fra 2001 og frem til 2007 blev der fra den danske regerings side besluttet en udstrakt privatisering af fiskekvoterne. Først med forsøgsordninger, der siden blev gjort permanente, og i 2007 blev så størstedelen af de danske konsumarter (som torsk, rødspætte, jomfruhummer og tunger) privatiseret og uddelt som fartøjskvote-andele baseret på fartøjets fiskeri de forudgående tre år. Selv set i international kontekst er der tale om en meget omfattende privatisering af fiskekvoter. Værdier til flere milliarder kroner blev givet til de danske fiskere. Det var derfor også meget rammende, da den daværende fødevareminister Hans Christian Schmidt kaldte det for „den største revolution i danske fiskeri de sidste 20 år“. Det var en privatisering på linje med 1800-tallets landboreformer. Med kvoterne på private hænder samt som pant i banker kunne kvoteejerne nu købe kvoter af hinanden og dermed fordele fiskerimulighederne ved hjælp af markedskræfterne. Salg og pantsætning af kvoterne skabte en tiltrængt likviditet for fiskerne hver især og ikke mindst for den statsligt styrede Fiskeribank, der i 2005 havde udlån for 1,7 mia. kroner. En række fiskere fik mulighed for at komme ud af erhvervet og betale deres gæld af, mens andre oplevede det som en nyvunden frihed igen at kunne ekspandere og intensivere fiskeriet. 


\section{En ny(liberal) hverdag}

Efter at den daværende regering i 2007 havde uddelt fartøjskvote-andelene, altså retten til at fiske en bestemt mængde af Danmarks kvote i et bestemt fangstområde, kunne fartøjsejerne som nævnt nu købe, sælge og leje kvoterne mellem hinanden. ${ }^{1}$ Mange oplevede dette som en pludselig grad af frihed efter mange års stigende bureaukratisering. Ikke bare kvoterne, udstykket som promiller af Danmarks årlige nationale kvote, men også andre af de tidligere reguleringsinstrumenter og licenser, så som kilowatt (retten til motorkraft) og havdage (antal af tilladte fiskedage) kunne nu handles. De forskellige reguleringsinstrumenter, der tidligere skulle begrænse vækst og nybygninger i fiskeflåden blev nu altså til grundlaget for ekspansion. På havne, hos revisorer og via skibsmæglere blev der købt og solgt ivrigt i de første mange måneder og år. Kvoterne havde fået tilføjet en individuel bytteværdi, og det gav kvoteejeren en helt ny situation:

„Lige pludselig da året det var omme og båden blev skrevet op - den røg lige to tre millioner op i værdi, kvoten ikke, på et år. Revisoren sagde, det var noget af et hug. Bankmanden kom og gav mig hånd og lykønskede mig, tillykke med titlen, jeg var en af de der millionærer.“ (Fartøjsejer \#1).

Kvoten var altså blevet en vare, og dens værdi kunne realiseres eller bruges som pant til at købe flere kvoter. I det følgende vil jeg forsøge at se nærmere på kvoten som en vare for kunne forstå, hvordan fiskere og fartøjsejere handler og anskuer forholdet mellem fisk og kvote. Privatiseringen af kvoterne medførte flere subtile men grundlæggende ændringer. Først og fremmest var fisken ikke længere noget, der skulle fanges, men tilhørte teknisk set fartøjsejeren som en genstand, der nu skulle hentes ind. Den nye kvote var dog ikke bare en almindelig vare, som dem vi kender i supermarkedet. I lighed med for eksempel landjord, arbejdskraft og penge er fiskekvote samfundsmæssigt skabt, forhandlet og til stadighed opretholdt (se Polanyi 1957). Kvoternes kunstigskabte og forhandlede karakter giver

1 Privatisering af fiskekvoter og etablering af et kvotemarked kan ses som en neoliberal forvaltningsform, hvor staten skaber et marked til at løse en særlig forvaltningsudfordring, og dermed udvider markedskræfternes domæne (Davis og Ruddle 2012; Harvey 2005; Mansfield 2004). Samtidig frakobles en del af styringen og ansvaret fra den politiske forvaltning og neoliberaliseringen kædes ofte sammen med en øget ulighed og kapitalisering af økonomien (Harvey 2005). En sådan neoliberal fiskeriforvaltning har været indført i andre lande og antropologiske, kulturgeografiske og sociologiske studier har her påpeget de forandringer det har medført. De kultur-sociologiske studier har ofte drejet sig omkring de socioøkonomiske konsekvenser, der ofte viser sig som en hurtig og voldsom koncentration af ejerskabet (se blandt andre; Cardwell 2012; Duncan 2011; Einarsson 2011; Hersoug 2005; Højrup og Schriewer 2012; McCay og Jentoft 1998), mens der i økonomiske kredse føres bevis for de økonomiske fordele ved den hurtige rationalisering (se blandt andre; Arnason 1996; 2002; Bromley 2009; Grafton 1996; Macinko 2002; Mansfield 2004; 2008; Olson 2011; Squires, Kirkley og Tisdell 1995) 
dem flertydige egenskaber. Anskuet på den ene side som råvare giver kvoten adgang til en mængde fisk, der kan fanges og sælges på auktionen. Kvoten kan dog på den anden side også anskues som en kapital, der som i citatet ovenfor pludselig skabte nye millionærer. Disse to egenskaber binder fisken sammen som en naturressource, råvare og kvote, der kan handles og forvaltes på land. Som en årlig uddeling af kilo forsvinder den, hvis den ikke bruges inden udgangen af året, men fornyes samtidig ved årsskiftet med en ny mængde. I mellemtiden kan den være lejet ud, opfisket eller være ubrugt. Men modsat andre varer i supermarkedet, så kommer der ikke flere kvoter til: ingen nye eller billigere fiskekvoter vil komme ind på markedet og konkurrere med dem, der allerede er blevet delt ud. Her er altså en begrænset vare, som kan købes op og monopoliseres, eller lejes ud som „lejefisk“, i lighed med for eksempel landjord eller mælkekvoter. Selv for revisorerne var det ikke lige til at vurdere, endsige at forudsige, kvoternes fremtidige værdi. Samtidig var kvotemarkedet nu det helt centrale element i distributionen af fiskerimuligheder mellem personer, generationer og forskellige egne i Danmark. Fiskeriforvaltningen havde endnu en gang gennemgået en paradigmatisk forvandling.

\section{Kvotevaren}

Centralt var nu kvoten som handelsvare. For at forstå denne udvikling kan man sammenligne det med den udvikling, som Marx beskriver i første bind af „Kapitalen“. Da han skal forklare det kapitalistiske system, begynder han netop med en analyse af varen, som fremstår som det mest centrale element i kapitalismen (Graeber 2001; Harvey 2010; Marx 1976). Varer kan anskues, argumenterer Marx, fra et kvalitativt og et kvantitativt perspektiv. Disse to perspektiver kommer i Marx’ terminologi til at udgøre henholdsvis varens brugsværdi og dens bytteværdi. Bytteværdien kommer af, at varen kan byttes eller handles med andre varer, herunder penge(varen). Her har vi fiskekvoten anskuet som kapital, der som i citatet ovenfor kan omsættes i penge. Brugsværdien er for Marx heterogen og historisk varierende, og Marx fortsætter sin analyse for at finde varens værdi. En vares værdi må ifølge Marx være andet end dens pris, som blot er pengenavnet for værdi. Kort fortalt, så finder Marx sit værdibegreb i den ,samfundsmæssigt nødvendige arbejdstid“, altså den gennemsnitlige tid det vil tage gennemsnitlige arbejdere at producere en given vare i et givent samfund. Her møder vi dog en udfordring i sammenligningen med fiskekvoter. For hvor det virker forholdsvist ligetil at se bytteværdien i kvoten, som den kapital revisoren også noterer sig, er det langt sværere at argumentere for, at bytteværdien skulle kunne måles i arbejdstid, da fiskekvote jo netop ikke er skabt af menneskeligt arbejde - med mindre vi inddrager de biologer, politikere og bureaukrater, som hvert år tager 
del i at udregne, forhandle og dermed opretholde kvoten som forvaltningssystem. Hvorfra kommer så den værdi, der handles med på kvotemarkedet? Det ville være fristende at foreslå, at kvoten, der jo er en rettighed til fremtidigt fiskeri, på en eller anden måde repræsenterer fremtidig arbejdstid i et antal af de kommende år. Sådan taler nogle fiskere tilsyneladende nemlig også om den:

„Hvis de [andre fiskere] køber et kilo torsk til 130 kroner, der går mange år inden du har tjent dem ind igen. Så siger folk vi kan da bare sælge dem [kvoten] igen. Ja, men hvis I ikke skal sælge dem, hvor mange år tager det ikke før de er tjent ind igen. Der går i hvert fald 12 år inden I har tjent de torsk ind, for I har dem kun en gang hvert år.“ (Fartøjsejer \#2).

Et kilo kvote er altså dyrere end det et kilo fisk kan sælges til på fiskeauktionen og måles derfor som her i citatet i det antal af år, den skal fiskes, før den er tjent ind. ${ }^{2}$ Citatet indikerer derfor en forbindelse mellem de fremtidige fiskerimuligheder, arbejdstid og så kvotens værdi. Jeg vil vende tilbage til dette spørgsmål senere og i første omgang nøjes med at notere, at en privat bytteværdi er blevet tilføjet til kvoten, og at dette er et radikalt nyt element, der samtidig gør markedskræfterne til den primære distributør af fiskemuligheder. Da kvote-andelene og privatiseringen blev indført, skete det med en lovgivning, der samtidig skulle sikre, at kvoteejerskabet forblev på fiskernes hænder, og at der ikke skete en for stor koncentration af kvoterne på for få selskaber. Lovgivningen skulle altså på én og samme tid både åbne op for kvotehandel og forsøge at forme og begrænse den. I det følgende afsnit vil jeg kort belyse denne dobbelthed i lovgivningen, der altså skulle favne kvotevaren som både brugs- og bytteværdi og som bindeled mellem fisk og fiskere.

\section{Ny regulering, ny forvaltning}

Da kvoterne blev privatiseret og uddelt som omsættelige kvoteandele, skete det på basis af en ny lovgivning, der skulle styre og forme handlen efter de politiske ønsker og de forskellige hensyn blandt fiskerne (Ministry of Food and Agriculture 2005). I det følgende vil jeg kort gennemgå de vigtigste regler med særligt fokus på, hvordan reglerne har formet kvotemarkedet og handlerne, og modsat hvordan kvotehandlen hurtigt har udfordret forvaltningen af den nye regulering. For at forstå reglerne er det vigtigt at nævne, at kvoterne rent teknisk set blev uddelt til

2 Kvoterne, som handles, er teknisk set udformet som promiller, altså en relativ andel af de samlede danske fangstrettigheder af en art i et farvand. Kvote-andelen udløser hvert år en årsmængde, som måles i kilo, og det er typisk denne mængde, der tales om og som prissættes, og som i øvrigt også er den form (altså kilo) kvoten har som udlejningsvare. 
fartøjerne. Det er således ejerne af fartøjet, der ejer kvoten, og kvoten kan (i princippet) kun sælges videre ved at sælge fartøjet. Da reglen om, at fiskefartøjer skal være 2/3 ejet af erhvervsfiskere blev videreført fra den tidligere forvaltning, er 2/3 af kvoterne som udgangspunkt altså også ejet af erhvervsfiskere. Samtidig muliggør det dog også, at 1/3 kan være investeringer udefra og dermed i princippet kan være spekulation i kvotens værdi. Ejeren af denne sidste tredjedel kan nemlig havde ejerandele i en række af selskaber eller fartøjer - altså flere tredjedele. Andre konstruktioner opfylder formelt de lovtekniske krav, men udfordrer fiskerens uafhængighed som ejer. Hvilken status har en fisker i et aktieselskab, der ejes af et holdingselskab, og som er finansieret gennem private gældsbrev? Har han eller hun selv investeret de 20-30 millioner, der er skudt i selskabet, eller arbejdes de af over mange år med rente til de andre ejere? Ligeledes er der i de senere år også set udenlandske selskaber, der i alliance med danskere køber kvoter i Danmark. Hvad betyder det for ejerskabet, at en svensk bank har pantrettigheder i dansk fiskekvote? En erhvervsfisker kan også eje flere både og have mandskab på dem til at fiske for sig, hvorefter bådejeren aflønnes gennem bådparten eller gennem udlejning af kvoter til fiskerne. Det er derfor teknisk set stadig en erhvervsfisker, der ejer fartøjet og kvoten, men det er spørgsmålet om denne udvikling var tiltænkt (eller gennemtænkt). Kvotemarkedet har altså på kort tid skabt en række nye udfordringer til forvaltningen af ejerskabet, og nye virksomhedskonstruktioner har vist sig. Det samme gør sig gældende for de regler, der skulle regulere og forhindre koncentrationen af kvoterne. I den ny regulering blev det fastsat, at en fartøjsejer maksimalt kunne købe og overføre kvoter fra fire fartøjer til sit eget. Da kvoterne teknisk set blev delt ud til fartøjerne, skulle kvotehandel foregå gennem køb af fartøjer, og for at undgå uønsket koncentration blev der altså sat en grænse på fire køb. Denne fremgangsmåde lød umiddelbart også fornuftig, da den balancerede den ønskede rationalisering af fiskeflåden med et øvre loft på koncentrationen af ejerskab. Men formuleringen var i praksis upræcis på flere måder. Hvad med køb af fartøjer, der allerede var sammenlægninger af andre fartøjer, skulle disse tælles som et eller flere fartøjer? De fire fartøjer kunne teoretisk set hver især bestå af fire fartøjer, der kunne bestå af fire fartøjer, og så videre. Et eksempel af de mere ekstreme slags er fiskefartøjet HM45 „RIP“ ejet af selskabet August A/S. ${ }^{3}$ I januar 2008 blev HM45 solgt af August A/S for 370.000 kroner til tre købere. Blandt køberne var udover en dansk fisker, et hollandsk selskab men også den bestyrende reder i August A/S, altså det sælgende selskab. Tre uger senere blev HM45 solgt tilbage til August A/S, nu til en pris på over 32 millioner kroner. Det store beløb taget i betragtning kan man undre sig over, at HM45 „blot“ er en jolle på under fem meter, uden styrhus, uden motor og uden nogen registreret fangst. Det er

3 Se eventuelt http:/ / skibsregister.dma.dk $/$ Main.asp?CSR $=1172380 \& S I D=6235713 \&$ VID $=5143175 \&$ $\mathrm{A}=1 \& \mathrm{D}=4$ 
altså kvoterne på HM 45, som hovedsageligt er handelsvaren, og i den optik er en glasfiberjolle måske en optimal løsning. Formelt skal kvoten handles med et fartøj, og der er færre udgifter til vedligeholdelse og havneafgift med en inaktiv jolle som „kvotefartøjet“. Med sådanne handler har både fisk og fartøj fået en ny og sekundær rolle i handlen. Den lille jolle blev handlet med kvoter til næsten $5 \%$ af Nordsøens rødspætter, svarende til næsten 400.000 kilo rødspætter (2008). Ser man på August A/S som helhed, ejede selskabet efter flere handler i 2008 store kvoter af fisk, heriblandt ca. $8 \%$ og $10 \%$ af rødspættekvoterne i henholdsvis Nordsøen og Skagerrak. Ud over „RIP“ var der i selskabet fire andre joller (herunder „RUP“ og „RAP“), samt syv andre fartøjer af forskellig størrelse. Den oprindelige fire-fartøjsregel viste sig altså i praksis at kunne omgås, og med tiden viste det sig at være endnu nemmere end i eksemplet ovenfor. For formuleringen i reguleringen lød på, at det maksimalt var tilladt at købe og overføre kvoter fra fire fartøjer. Det blev med tiden fortolket som, at et selskab kunne købe ligeså mange fartøjer, det ønskede, men at kun fire af dem kunne overføres permanent til det samme fartøj. Med brug af lejesystemet kunne ejeren leje fisk fra de resterende fartøjer af sig selv og til sig selv og derved undgå at overføre kvoten. Med denne fortolkning var koncentrationsreglen i praksis virkningsløs. I 2012 blev der derfor indført nye regler baseret på en maksimal procentsats. I indstillingsnotatet kunne ministeriet konkludere: „De nuværende koncentrationsregler for FKA[fartøjskvote-andele]fartøjer har med tiden blandt andet medført, at nogle fiskere er tvunget til at have kvoteandele liggende på fartøjer, som aldrig kommer ud at fiske“ (Ministeriet for Fødevarer 2011). Ligeledes kunne ministeriet afsløre, at fartøjsejerne under de tidligere koncentrationsregler kunne „eje lige så mange fartøjer de har lyst til“ (Ministeriet for Fødevarer 2011). De gamle regler ministeriet havde udformet i 2006 var altså virkningsløse, mens de nye regler satte en maksimal procentsats for ejerskabet. Procentsatsen i de nye regler veksler afhængigt af arter og farvande mellem $5 \%$ og $10 \%$. Spørgsmålet er, om ministeriet denne gang har formået at dæmme op for kreativiteten på kvotemarkedet? Som det er formuleret i det nye regelsæt fra 2012, kan et selskab, der ejes af to individer og som har to fartøjer, opnå en fordobling af maksimumsatsen ved hvert år at leje fra det ene fartøj til det andet. Udviklingen har altså vist, at lovgivningen var udformet tilpas tvetydigt, så den på en gang åbnede op for udefrakommende investeringer og samtidig forsøgte at holde ejerskabet blandt fiskerne. Udviklingen har også vist, at forvaltningen har haft svært ved at forvalte de frie markedskræfter efter de oprindelige politiske hensigter. Eksemplerne ovenfor hører måske til de mere ekstreme, men understreger den grundlæggende pointe, nemlig at kvoten som handelsvare har forandret forholdet mellem fisk, fiskere og forvaltning. Bytteværdien er blevet et kompleks i sig selv, med lovgivning, særlige specialister og med implikationer for den bagvedliggende brug og udnyttelse af havets ressourcer. Kvoten som handelsvare er nu den væsentligste værdi i fiskeriet og indgår i fiskernes dagligdag. 
I det følgende afsnit vil jeg give en række empiriske eksempler på køb og salg af kvote, for at vise nogle af de forskellige ræsonnementer, der ligger til grund for transaktionerne på kvotemarkedet, og hvordan fisken som kvotehandelsvare binder fiskernes praksisser sammen med naturressourcen.

\section{Det spekulative blik}

Vender vi os mod de mennesker, der er involveret i handlen med kvoter, så finder man hurtigt ud af, at udviklingen i markedsprisen nu også er blevet en væsentlig del af deres dagligdag. Bytteværdien giver kvoteejeren et nyt problemfelt, en ny række af spørgsmål, der skal indhentes viden om og nogle nye slags usikkerheder, som han eller hun skal forholde sig til. Hvad er kvoten blevet handlet til, hvad lejes den ud for, og lignende spørgsmål kommer dermed til at præge hverdagens gøren samt snakken på havnene. Samtidig giver bytteværdien også mulighed for nogle nye måder at anskue og leve af kvoten på. Det er nemlig ikke bare revisoren eller den kvotepuljebestyrer, som forestår ind- og udlejning af kvoter, der får mere at lave. Kvotens bytteværdi gør det muligt at investere i kvoten og åbner fiskeressourcen op som et felt for investorer og i princippet også for spekulation. Dette spekulative blik er dog ikke kun forbeholdt spekulanter, men er ligeså blevet en del af kvoteejerens strategiske perspektiv. Det dynamiske økosystem producerer nemlig svingninger i kvoterne, der ikke bare påvirkes af fiskeriet, men også af klimaændringer, forurening samt andre menneskelige praksisser - inklusive fejlagtige målinger eller antagelser i de biologiske modeller. Få fiskekvoter er stabile fra år til år, og dette giver mulighed for at spekulere i disse svingninger. Et sådant perspektiv er de fleste kvoteejere nødt til forholde sig til, da kvoterne i mange tilfælde udgør mere end 80 \% af fartøjets værdi (Skibsmægler \#1, 2010). Særligt kvoteejere på vej til at trække sig tilbage, købe eller sælge, må forholde sig til skiftende kvoter og svingninger i priserne (Fartøjsejer \#3, 2010, Fartøjsejer \#4, 2011). Få måneder kan betyde meget i forhold til de svært forudsigelige prissvingninger på kvotemarkedet.

\section{Køb og salg}

Privatiseringen førte til en koncentration af fiskekvoterne på færre hænder, hvilket til en vis grad også var meningen med systemet. I den økonomiske litteratur forklares denne koncentration med, at de dygtigste fiskere (i en økonomisk forstand) er i stand til at købe sig til en større del af fangstmulighederne (kvoterne), og at det derfor stille og roligt er de mest effektive fiskere, der kommer til at fiske 
mest. ${ }^{4}$ Dette fører til, at fiskeriet er mere rentabelt for samfundet, da fiskeressourcen fanges mere effektivt, hvorefter den kan beskattes af for eksempel stat og kommune. Set fra et etnologisk blik, der inddrager samtaler med skibsmæglere og fiskere, så viser der sig nogle helt andre mønstre end det formodede økonomiske ræsonnement. For det første var nogle fartøjsejere godt forberedt på kvotemarkedet og gik i gang med at lave købsaftaler, inden systemet blev endeligt iværksat:

„Så kom det her på tale. Så læste jeg en masse rapporter fra Island, Skotland og Tyskland, som havde indført det før os. Individuelt Omsættelige Kvoter, der var en masse rapporter på det - og det studerede jeg en hel del. Og kunne se, og min partner kunne også se mulighederne i det. Enten skulle vi sælge eller også skulle vi købe. Så begyndte vi at købe op inden det var en realitet, det blev bestemt i oktober 2005, og der havde vi allerede købt de første to fartøjer.“ (Fartøjsejer \#5, 2011).

Med bankaftaler og investorkapital på plads allerede inden systemet var trådt i kraft, begyndte enkelte rederier tidligt at opkøbe fartøjer i formodning om, at man senere kunne overføre kvoten til hovedfartøjet. Modsat var der en lang række af andre fartøjsejere, som ikke havde forberedt sig og som havde svært ved at sige nej, da deres fiskevirksomhed for første gang i mange år pludselig kunne realiseres med et overskud. Samtidig steg priserne støt på de kvoter, der blev handlet det første års tid i det nye system (fra 2007):

„Ja, mens vi stod her og kiggede, hvad sker der her, og vores formand han står bare og ser, og de gik bare og købte rundt om os, og vi blev budt det ene efter det andet. Og der var vi kun oppe at snakke 1,2 det var helt vildt, og i dag kan de få 3 millioner. Det de solgte for 1,2 dengang, det var jo kæmpepenge, en båd steg fra 450.000 til 1,2 og folk røg jo bare på den med begge ben.“ (Fartøjsejer \#1, 2011).

Det har uden tvivl været svære beslutninger for rigtig mange, men med en generel høj gennemsnitsalder i sektoren, høj gældssætning og med kvoter, der knapt var store nok til at overleve på, valgte mange at sælge i den første tid. Således fortæller en fisker og fartøjsejer, at han var slidt op efter mange år på havet, at hans

4 For eksempel: „Transferability of the harvesting rights allows fishers with higher returns per unit of fish to increase their share of the harvest and, thus, should increase the rents from fishing. Consequently, with the adoption of ITQs there is a potential for increased profitability of vessels and the fishing industry." (Dupont, Fox, Gordon og Grafton 2005:32) eller: "The theory behind ITQs suggests that in certain fisheries they can be an effective management tool to prevent rent dissipation and can increase the returns to fishers and the resource owners." (Grafton 1996:17) 
„,sildemakker“ allerede havde solgt, men også at han ikke ønskede at skulle tage lån for at købe mere kvote: ${ }^{5}$

„Hvis der skulle være en levevej ud af det så skulle du ud og købe. [...] Størstedelen vil nok betakke sig fra at gældsætte sig når de kan se slutdatoen. [...] Jeg fik efterspørgsler udefra og da et af dem blev konkretiseret til 1,8 mio. spurgte jeg lokalt om, der var nogen her der var interesseret $\mathrm{i}$ at købe til den pris, for at holde fisken lokalt.“ (Fartøjsejer \#5, 2011).

Alder og især forbehold mod at tage nye lån har, sammen med en række af andre faktorer, indvirket på beslutningerne om at sælge eller købe. I eksemplet ovenfor forsøger sælgeren oven i købet at kombinere markedsmekanismerne med sin loyalitet over for den lokale havn. Enkelte steder gik fiskere sammen om at købe kvote ind i flok efter aktie- eller andelsprincipper (se blandt andet Andresen og Højrup 2008). Andre solgte deres kvote for så at leje kvote tilbage igen. Med pengene fra kvotesalget kunne bil og hus betales ud, og med færre faste omkostninger kunne fiskeren nøjes med tage på havet, når der var penge at lave på „lejefisk“ (Fartøjsejer \#6). Bytteværdien er altså rodfæstet i vidt forskellige praksisser eller udnyttelse brugsværdierne, hvis man skulle følge Marx’ terminologi. På den måde blev de danske konsumkvoter redistribueret ikke bare til den mest effektive fisker, men på mangfoldige måder. Der synes dog at være en generel erfaring, som kan gøres på trods af disse mange forskelligheder: adgang til finansiering og banklån har fået en dominerende indflydelse på, hvem der køber kvoten. Det er en særlig udfordring for unge eller nystartede, der jo ikke har nogen kvote i forvejen, og som derfor må leje eller tage lån. På fiskernes internetforum (fiskerforum.dk) diskuteres disse processer i systemet med de private fartøjskvoteandele (FKA-systemet):

„syntes ikke der bliver givet nogen hjælp til ny-starter idag med det fka-system. kan ikke tjene penge på at gi’ så høj en leje for fisk!!!jeg mener at det er grotesk at flere af dem der har solgt deres fartøj, stadig sidder på kvoten selvom de arbejder i land. flere af de store køber bare mere kvote op for at slippe for skatten. mens vi små må se os slået. med en bank rente på 12-13\% kan vi umuligt få en fremtid som fisker med egen båd“ (Fiskerforum 2013). ${ }^{6}$

5 En af måderne at fange sild på er med et trawl trukket af to både, og i dette tilfælde har den sædvanlige sildemakker altså allerede solgt sin båd (og kvote), og fiskeren her skal altså ud og finde en ny "sildemakker“.

6 http://fiskerforum.dk/debatforum/debatforum.asp?mode=viewmsg\&ld=3854\&ForumID=10\&Sho wsub=3859 (Fra september d. 15, 2012) 
Med en bankrente på 12-13 \% kæmper den unge mand en ulige kamp mod store rederier, som kan finansiere lån ned til $2 \%$. En ulige kamp der giver den afgørende forskel, når der skal tages lån og købes kvoter, og som umuliggør en „,fremtid som fisker med egen båd“. En anden ung fisker bidrager til diskussionen og foreslår, at den første i stedet skulle forsøge sig med et generationsskifte, hvor man lidt efter lidt køber en etableret kvote- og fartøjsejer ud. Dette får en tredje fisker til at reagere kraftigt:

„,bare et lille spørgsmål du siger at du fik god hjælp men kan du kikke dig i spejlet og sig jeg er skipper og jeg bestemmer selv næppe der sidder nok en reder som ser dig som en god vej ud af fiskeriet når han ikke gider slårs med sin kæmpe gæld mere.“ (Fiskerforum 2012). ${ }^{7}$

Muligheden for at være „skipper på egen båd“ er med kvotemarkedet blevet betydeligt dårligere, mens nye muligheder og udfordringer venter for dem der investerer. Finansielle omkostninger styrer den overordnede fordeling af fiskemuligheder, og her taber særligt de unge nystartede fiskere, der ikke var med da kvoten blev privatiseret i 2007. Dette skaber en gruppe af kvoteløse fiskere, som er afhængige af lejemarkedets muligheder. Transaktionerne på kvotemarkedet er altså mere komplekse, end hvad den økonomiske teori foreslår. Det er altså ikke nødvendigvis den mest effektive fisker, men adgangen til „fisk“ som er afgørende på længere sigt. Køb og salg er som vist ovenfor rodfæstet i forskellige praksisformer, og særligt muligheden for at blive selverhvervende skipper er, som de ovenstående citater viser, blevet forringet. Et flertal af fiskere er afhængige af at leje kvote for at kunne tage på havet. I det næste afsnit vil jeg argumentere for og belyse, hvordan lejemarkedet er blevet et helt centralt element i opretholdelsen af kvoternes og dermed fiskens værdi som råvare.

\section{Lejefisk og monopoler}

Ejeren af en kvote kan vælge at leje denne ud, og fiskerne kan melde sig ind i et puljesystem, hvor de ved hjælp af internettet kan leje fisken frem og tilbage. Lejesystemet er oprindeligt etableret for at give fiskerne fleksibilitet. Ved for eksempel at leje en art ud og en anden ind, kan der fokuseres på det fiskeri, som er mest rentabelt på et givent tidspunkt. Ligeledes kan fiskerne undgå at skulle smide noget ud, da de hurtigt kan leje kvote ind, hvis de fanger noget, som de ikke har kvote til. Men lejesystemet har også udviklet sig til at være en bærende

7 http://fiskerforum.dk/debatforum/debatforum.asp? mode=viewmsg\&ld=3854\&ForumID=10\&Sho wsub=3859 (Besøgt september d. 15, 2012) 
levevej for de nystartede, der ikke ejer kvote selv, eller for dem der ikke i deres oprindelige uddeling har nok. Selv store rederier kan være afhængige af lejefisk for at kunne drive deres fiskeri hele året. Men udover disse muligheder muliggør lejesystemet investeringer i kvote blot for at leje den ud igen. I det følgende citat fra et interview beskriver fiskeren en anden kvoteejer, som netop udpræget har købt ind for at leje ud:

„Det er fordi i de senere år har du kunnet leje fisk ud og tjene penge på det. Men den vender nu her. Fordi det ser ud til at mængden er på vej ned og fiskerne er på vej væk. Du kan ikke bare fjerne alle fiskerne og så tro, at du kan leje ud stadigvæk til dem samme pris. Han opkøber alle bådene. Jeg forstår ikke rigtig hans strategi. Så vil han leje ud stadig og tjene penge på det, fordi renten er så lav.“ (Fartøjsejer \#5).

Forudsætningerne for at kunne leje ud er altså ifølge fiskeren her på den ene side lav rente og på den anden side kvoteløse fiskere. Det er som beskrevet ovenfor selvfølgelig ikke alle, der har adgang til en lav rente, og denne ulighed danner grundlag for, at udlejning af fiskekvoter kan være en selvstændig forretningsform. Men en modsætning er indbygget i strategien, som det også bliver nævnt i citatet ovenfor. For hver gang en fisker købes ud af erhvervet, er der én færre til at leje fisk af kvoteejeren, og det kan på sigt true forretningsformen, hvis altså ikke der kommer nye til. Jeg har tidligere i denne artikel været inde på, hvordan kvotemarkedet kunne forstås med udgangspunkt i begreberne brugs- og bytteværdi. Bytteværdien er blevet det overvejende distributionskompleks og et centralt element fiskernes daglige og årlige aktiviteter. På den anden side har fartøjsejerne heterogene måder at udnytte kvoten på og knytter forskellige brugsværdier til denne - såsom for eksempel, at den forblev lokalt. De to værdibegreber var udgangspunktet for Marx’s analyse af den kapitalistiske vare. Værdien af disse varer var ifølge Marx et produkt af den samfundsmæssige nødvendige arbejdstid, der skulle til for at producere varen. Som jeg tidligere har nævnt, er fiskekvote ikke en vare fremkommet ved menneskeligt arbejde, men gennem administrative og politiske processer. Derfor giver det ikke umiddelbart mening at forstå kvotens værdi med udgangspunkt i den nødvendige arbejdstid. Heller ikke en mere spekulativ tese om, at kvotens værdi repræsenterer værdien af fremtidig arbejdstid synes gangbar. Selvom der tales om og regnes på kvoten som et antal af år ud i fremtiden, kan det for eksempel ikke forklare, hvorfor det er fire år i Østersøen og tolv i Nordsøen. Det er heller ikke klart, hvad forholdet er mellem bytteværdien og så lejeprisen. Udover arbejdstidsværdiloven beskrevet her, udviklede Marx også en værdilov baseret på grundrente (Marx 1981; Ramirez 2009). For at forstå dette princip kan man - som Marx gør det - forestille sig to identiske produktioner, med den eneste forskel, at en af dem udnytter vandkraft i sin produktion, 
mens den anden bruger kulfyrede dampmaskiner. Hvis man antager, at de producerer til samme marked, vil den første være i stand til at producere varerne billigere end den anden, der må betale for kul. Denne forskel resulterer i en merværdi til den ene af producenterne, som skyldes den fordelagtige sammensætning af kapital, arbejdskraft og den eksklusive brug af naturkræfter. Sidstnævnte er kun til rådighed for dem ,der råder over særlige stykker af jorden og de dertil hørende rettigheder“ (Marx 1972, s. 838). Denne eksklusive adgang til en naturressource resulterer i en merværdi, som ikke kommer fra investeringer i produktionsmidler eller arbejdstid, men fra de eksklusive naturforhold. Da der er begrænsede mængder af denne naturressource, opstår der en monopolfordel for ejeren, som kan producere ikke bare en almindelig profit som andre producenter, men også en merværdi. Den begrebsmæssige adskillelse af overskuddet i profit og merværdi giver Marx mulighed for at isolere sidstnævnte som grundrente, altså den værdi som tilfalder ejeren af grunden - eller i bredere forstand naturressourcen. Overfører vi denne situation på fiskeriet, har vi på den ene side en række kvoteejere, som har adgang til en begrænset og eksklusiv naturressource, og på den anden side en række producenter som ikke har - nemlig de kvoteløse. Forstået gennem dette perspektiv kan lejesystemet anskues som der, hvor kvoteejere trækker grundrenten ud via udlejning af deres kvoter. Kvoten er i denne optik det redskab, der forarbejder naturen til en råvare, der kan monopoliseres og kommercialiseres. På lejemarkedet sættes lejeprisen dynamisk som en prissætning mellem kvoteejere og kvoteløse - og i relation til de svingninger, der er i markedspriser og udgifter til produktionen. Går prisen op på fangsterne, kan kvoteejeren presse lejeprisen op og dermed trække en større grundrente ud. Lejepriserne kan altså forstås som udtrækning af grundrenten, men hvad med de handler, hvor kvoten skifter hænder permanent? Hvad er grundlaget for kvotens handlede bytteværdi? Også her kan vi komme nærmere et bud. Som en konsekvens af, at kvoten er blevet en investering - købt for at indbringe indtægter gennem udlejning - skal den give et afkast, der matcher det afkast investeringen kunne have givet andre steder. Der er altså en forbindelse mellem værdien af kvoten og lejeprisen. ${ }^{8}$ Anskuet sådan bliver monopolsituation ikke blot en uheldig konsekvens, men pludselig det grundlæggende princip for kvotens værdi.

\section{Konklusioner}

Set fra nutidens perspektiv er fiskekvoter et helt central element i det danske fiskeris historie. I denne artikel har jeg undersøgt fiskekvoter som et dynamisk

8 Lejes fisk ud til 5 kroner kiloet og det antages, at det gennemsnitlige afkast på investeringer er $8 \%$ i resten af samfundet, så er kvoten anskuet som kapitalværdi lig med 62,50 kroner (lejepris / gennemsnitlige profitrate $\mathrm{i} \%$ = kvotens værdi). 
bindeled mellem fisk, fiskere og forvaltning. Fiskekvoter har ikke blot været en passiv øvre grænse for fiskeriet, men har aktivt formet relationen mellem fisken som naturressource og så forvaltnings- og fangstpraksisserne. Med indførelsen af private omsættelige kvoter i 2007 etableredes en ny forbindelse mellem fisk som natur, råvare og kvote, og den nye markedsorienterede forvaltningsform skabte nye måder at anskue, skabe og opretholde fiskens værdi på. Dette giver nogle nye udfordringer og problemer. Som brugsværdi er kvoten nødvendig for at drive fiskeri, mens den som bytteværdi er mest værd, når der er en stor gruppe af kvoteløse. Er der ingen til at leje fisken, falder værdien således, hvilket er synligt i slutningen af året. Her forsøger kvoteejere ofte at trække en smule værdi ud af deres overskydende kvoter og overfylder lejemarkedet med efterfølgende prisfald. I et andet scenarie kan stigninger i den samlede kvote betyde, at værdien falder. Stiger Danmarks kvote på en art mange år i træk, bliver monopolsituationen nemlig svækket, da fiskere med små kvoter også får større mængder at fiske. Selvom man intuitivt skulle tro, at kvoten ville blive mere værd (ressourcen har det bedre), kan det føre til, at den faktisk bliver mindre værd som kvote. En anden risiko kunne være, at en af de store kvoteejere kollapser økonomisk. Dette ville kunne have stor indflydelse på lejepriserne, når konkursadvokaten begynder at leje de store mængder ud. Dette kan igen have stor betydning for de fiskere, der havde regnet med at sælge deres båd og kvote, for eksempel for at lade sig pensionere, eller dem som lige har købt ind. Som jeg har vist ovenfor er det muligt at kombinere Marx' abstrakte analyse med etnologisk feltmateriale. Finanskrisen har sat økonomi øverst på dagsordenen igen og gjort økonomisering til et hverdagsfænomen i stat, kommuner og hushold. Netop derfor fortjener de vestlige økonomiske videnskaber et modspil fra en samfunds- og kulturteori, der også kan rumme og tænke økonomien med - også som et kulturelt fænomen. Kapitalismen har de sidste årtier udviklet sig kvalitativt, og transnationale virksomheder erobrer større og større magt i forhold til de kriseramte europæiske stater. Samtidig har den kapitalistiske økonomi udvidet sit geografiske domæne og fundet vej til nye områder. Alt dette har indflydelse på indretningen af arbejdspladser og hverdagsliv - og kan studeres kulturelt og socialt. Et eksempel herpå er etableringen af det danske marked for fiskekvoter, der i øjeblikket har stor opmærksomhed fra europæiske bureaukrater som løsningen på mange års strukturelle problemer i det europæiske fiskeri (European Union 2009). I denne artikel har jeg diskuteret kvotemarkedet som et socialt konstitueret og kulturelt fænomen, der forbinder havets ressourcer med væld af praksisser på land. Samtidig er forvaltningen gledet ud af hænderne på fiskerne og den danske stat, og det er i stigende grad investorer, banker, advokater og revisorer, der distribuerer fremtidens fiskemuligheder. Som et led i denne proces er det blevet sværere at forfølge et liv som selverhvervende skipper, mens der er opstået nye muligheder for at gøre karriere og købe sig ind i de større rederier. På denne måde sameksisterer fiskekvoten som 
en skrøbelig kapitalinteresse sammen med de forskelligartede fangstformer, som med redskaber, både og menneskelig arbejdskraft udnytter havets råvarer.

\section{Litteratur}

Andresen, J. og T. Højrup 2008: „The Tragedy of Enclosure. The Battle for Maritime Resources and Life-Modes in Europe“. Ethnologia Europaea 38, 1: 29-41.

Arnason, R. 1996: „On the ITQ fisheries management system in Iceland“. Reviews in Fish Biology and Fisheries 6, 1: 63-90.

Arnason, R. 2002: A review of international experiences with ITQs. Centre for the Economics and Management of Aquatic Resources, University of Portsmouth.

Bromley, D. W. 2009: „Abdicating Responsibility: The Deceits of Fisheries Policy“. Fisheries 34, 6: 280-290.

Byskov, S. 2010: Fiskeriet der forsvandt : eksempler fra et dansk fiskerierhverv i opbrud 1990-2008. Fiskeri- og Søfartsmuseet.

Cardwell, E. 2012: „Invisible Fishermen. The Rise and Fall of the British Small Boat Fleet“. T. Højrup and K. Schriewer (red.): European Fisheries at a Tipping Point Estudios Europeos, No 1edit.um.

Davis, A. og K. Ruddle 2012: „Massaging the Misery: Recent Approaches to Fisheries Governance and the Betrayal of Small-Scale Fisheries“. Human Organization 71, 3: 244-254.

Duncan, L. (2011). The social implications of rights-based fisheries management in New Zealand : for some Hauraki Gulf fishermen and their communities. from http://hdl.handle.net/10289/5318.

Dupont, D. P., K. J. Fox, D. V. Gordon og R. Q. Grafton 2005: „PROFIT AND PRICE EFFECTS OF MULTI-SPECIES INDIVIDUAL TRANSFERABLE QUOTAS“. Journal of agricultural economics. 56, 1: 31.

Einarsson, N. 2011: Culture, conflict and crises in the Icelandic fisheries : an anthropological study of people, policy and marine resources in the North Atlantic Arctic. Acta Universitatis Upsaliensis.

European Union, T. 2009: Commission Green Paper on the Reform of the Common Fisheries Policy.

Graeber, D. 2001: Toward an anthropological theory of value : the false coin of our own dreams. Palgrave.

Grafton, R. Q. 1996: „Individual transferable quotas: theory and practice“. Fisheries Reviews in Fish Biology and Fisheries 6, 1: 5-20.

Harvey, D. 2005: A brief history of neoliberalism. Oxford University Press.

Harvey, D. 2010: A companion to Marx’s Capital. Verso. 
Hersoug, B. 2005: Closing the commons: Norwegian fisheries from open access to private property. Eburon.

Hjorth Rasmussen, A. 1968: Dansk fiskeri gennem 100 år. Fiskeri- og Søfartsmuseet.

Hjorth Rasmussen, A. 1984: Vejen til Nordsøen...: det søgående snurrevodsfiskeris gennembrud i Nordsøen og Skagerak 1884-1903. Nordsømuseet.

Holm, P. 2001: The invisible revolution : the construction of institutional change in the fisheries. Norwegian College of Fishery Science, University of Tromsø.

Holm, P. og K. N. Nielsen 2007: „Framing fish, making markets: the construction of Individual Transferable Quotas (ITQs)“. The Sociological Review 55, 173195.

Højrup, T. 1984: „Det fiskende menneske“. H. Meesenburg (red.): Bygd, Årg. 15, nr. 1 (1984)2-31.

Højrup, T. og K. Schriewer 2012: European Fisheries at a Tipping Point edit.um.

Karlsdóttir, H. M. 2005: Fishing on common grounds: the consequences of unregulated fisheries of North Sea herring in the postwar period. EkonomiskHistoriska Institutionen vid Göteborgs Universitet.

Macinko, S. B. D. W. 2002: Who owns America's fisheries? Center for Resource Economics.

Mansfield, B. 2004: „Neoliberalism in the oceans: „rationalization,“ property rights, and the commons question“. Geoforum 35, 3: 313-326.

Mansfield, B. 2008: Privatization: property and the remaking of nature-society relations. Blackwell Publishing.

Marx, K. 1972: Kapitalen. 3. bog: kritik af den politiske økonomi. Bd. 3. Rhodos.

Marx, K. 1976: Capital: a critique of political economy. Penguin Books.

Marx, K. 1981: Capital: a critique of political economy. Vol. 3. Penguin in association with New Left Review.

McCay, B. J. og S. Jentoft 1998: „Market or community failure? Critical perspectives on common property research“. Human Organization 57, 1: 21-29.

Ministeriet for Fødevarer, Landbrug og Fiskeri, 2011: Indstillingsnotat vedrørende ændring af koncentrationsregler for IOK og FKA i Reguleringsbekendtgørelsen. Ministeriet for Fødevarer, Landbrug og Fiskeri.

Ministry of Food and Agriculture 2005: New regulation. Ministry of Food and Agriculture: 1-5.

Nandan, S. N. (2012:online document). The Exclusive Economic Zone: a historical perspective. The law and the sea : essays in memory of Jean Carroz Retrieved 01-12, 2012, from http://www.fao.org/docrep/s5280T/s5280t0p.htm.

Olson, J. 2011: „Understanding and contextualizing social impacts from the privatization of fisheries: An overview“. Ocean \& Coastal Management 54, 5 : 353-363.

Polanyi, K. 1957: The great transformation. Beacon Press. 
Ramirez, M. D. 2009: „Marx’s Theory of Ground Rent: A Critical Assessment“. Contributions to Political Economy 28, 1: 71-91.

Rasmussen, B. K. S. og A. Hjorth Rasmussen 1972: Vestkysten. Nyt Nordisk Forlag.

Rozwadowski, H. M. 2002: The sea knows no boundaries: a century of marine science under ICES. International Council for the Exploration of the Sea in association with University of Washington Press, Seattle.

Squires, D., J. Kirkley og C. A. Tisdell 1995: „Individual transferable quotas as a fisheries management tool“. Reviews in Fisheries Science 3, 2: 141-169.

Søndergaard, M. K. 2004: Teknologisk udvikling i dansk fiskeri 1945-2000. Fiskeri- og Søfartsmuseet.

Søndergaard, M. K. 2008: Dansk fiskeri c. 1945-2005: teknologi, udvikling og forestillinger om kontrol. Syddansk Universitet.

Vedsmand, T., P. Friis og N. J. Raakjær 1996: The Danish fishing industry, structure, policy formulation and control of Danish fisheries. Roskilde Universitetscenter, Institut for Geografi og Internationale Udviklingsstudier.

Vedsmand, T. B. F. 1998: Fiskeriets regulering og erhvervsudvikling - i et institutionelt perspektiv. Bornholms Forskningscenter.

\section{Websider}

www.fiskerforum.dk (besøgt 15. September 2012)

\section{English Summary}

After a recent privatization of the Danish fish resources these are now distributed between fishers through market mechanisms. This article examines how this marketization has influenced and changed the manifold fishing practices and their relation to the fish resource. Buying, selling and in particular leasing have become central to the new everyday life of quota owners and leasers. It is argued that a life as an independent and self-employed skipper is becoming increasingly difficult. This is a result of the increasing importance of access to capital in the distribution of fish quotas. A main concern in the article is to find the central features that constitute the transactions on the quota market, and in order to do this the article finds inspiration in Marx's different theories of value. Using this analytical approach it can be argued that the central tenet in the market-based system is the unequal social situation between quota owners and quota leasers. It is this connection between exclusive ownership and leasing that forms the value of fish quota as a commodity. 